\title{
Sprawozdanie
}

\section{Wykład Prezydenta RP Aleksandra Kwaśniewskiego pt. Ćwierć wieku polskiej transformacji, 20 lat Konstytucji $R P$. Co dalej? wygłoszony 10 maja 2017 r. na Wydziale Matematyczno-Fizycznym Uniwersytetu Szczecińskiego}

10 maja 2017 r. na Wydziale Matematyczno-Fizycznym Uniwersytetu Szczecińskiego odbył się wykład byłego Prezydenta Rzeczypospolitej Polskiej Aleksandra Kwaśniewskiego, poświęcony polskiej transformacji ustrojowej, ładowi konstytucyjnemu będącemu jej konsekwencją oraz polityczno - ustrojowym przewidywaniom na przyszłość.

W spotkaniu udział wzięli przedstawiciele szczecińskiego środowiska akademickiego, w tym pracownicy naukowo-dydaktyczni, doktoranci i studenci. Gościa powitał i spotkanie otworzył JM Rektor Uniwersytetu Szczecińskiego prof. zw. dr. hab. Edward Włodarczyk. Po wykładzie nastąpiła dyskusja.

Zdaniem Prelegenta, docenianymi na Zachodzie zmianami, jakie zaszły w polskiej rzeczywistości w ciągu ostatnich 25 lat, są: demokratyzacja ustroju państwa, uwolnienie rynku, zwiększenie niemal o jedną czwartą produktu krajowego brutto per capita, przeniesienie ciężkości gwarancji bezpieczeństwa państwa z Układu Warszawskiego na Sojusz Północnoatlantycki oraz - co chyba najważniejsze - przeniesienie państwa ze sfery gospodarczej Rady Wzajemnej Pomocy Gospodarczej na łono integracji europejskiej i związane z tym przekierowanie niemalże całego eksportu na Zachód. Są to zmiany na skalę światową. 
W czym jednak tkwią źródła sukcesu polskiej transformacji, stosunkowo większego niż u naszych sąsiadów (np. w Czechach, na Węgrzech, w Rumunii czy na Ukrainie)? Zdaniem Prelegenta, źródeł tych doszukiwać należy się w sześciu okolicznościach.

Po pierwsze, w 1989 r. Polacy obrali drogę pokojowej ewolucji (kompromisowej i opartej na dialogu) w niemalże wszystkich sferach życia państwowego (w polityce, gospodarce i perspektywie geostrategicznej), której efekty okazały się mieć charakter rewolucyjny.

Po drugie, zdecydowano się na przeprowadzenie głębokich zmian politycznych i wprowadzenie demokracji „bez zbędnych przymiotników”.

Po trzecie, zdecydowano się na przeprowadzenie radykalnych zmian ekonomicznych zwanych terapią szokową autorstwa prof. Leszka Balcerowicza, co okazało się być korzystniejsze od zmian stopniowych z racji tego, że koszty społeczne miały charakter relatywnie krótkotrwały i szybko udało się je wygasić lub zminimalizować. Jednocześnie ważnym osiągnięciem gospodarczym było uporządkowanie finansów publicznych. Oczywiście nie uchroniło to Polaków przed wysokimi kosztami społecznymi, utratą miejsc pracy przez setki tysięcy ludzi, zamknięciem zakładów pracy etc.

Po czwarte, zdecydowano się na decentralizację władzy publicznej i wprowadzenie szerokiej samorządności do mechanizmów jej sprawowania, co doprowadziło do rzeczywistego upodmiotowienia obywateli. Namacalnym wyrazem sukcesu w tej sferze było przeprowadzenie pierwszych wyborów samorządowych już w maju 1990 r., czyli niespełna 11 miesięcy po tzw. wyborach czerwcowych.

Po piąte, dokonano dwóch strategicznych wyborów geopolitycznych. Z jednej strony podjęto decyzję o włączeniu Polski do północnoatlantyckiego systemu wspólnej obrony (NATO), odrzucając jedyną ówczesną ewentualność w postaci neutralności na wzór szwajcarski (która, zdaniem Prelegenta, miała sens jedynie w świecie dwubiegunowym), a z drugiej - nastąpiło włączenie Polski w proces integracji europejskiej, którego zwieńczeniem było uzyskanie członkostwa w UE w 2004 r.

Po szóste, opracowano i przyjęto Konstytucję Rzeczypospolitej Polskiej z 2 kwietnia 1997 r., która stała się fundamentem ustroju nowego państwa, a wręcz - jak wskazał Prelegent - kwestią jego bytu.

W dalszej części swych rozważań Prelegent skupił się na zagadnieniach konstytucyjnych. Postawił pytanie, co by się stało, gdyby obecnie obowią- 
zującej Konstytucji nie uchwalono. Z pewnością zapanowałby wówczas chaos konstytucyjny, który bez wątpienia zaważyłby m.in. na tak ważkiej materii jak ochrona praw obywatelskich. Zdaniem Prelegenta, nader ważne było to, że Konstytucja po uchwaleniu przez Zgromadzenie Narodowe miała uzyskać akceptację społeczeństwa w referendum. Dzięki tej akceptacji, a także dzięki przyjęciu ustawy zasadniczej w określonym momencie historycznym, udało się przełamać złą passę polskich konstytucji. Nie da się przecież nie zauważyć, że Polska nie miała szczęścia do ustaw zasadniczych, podobnie jak np. Stany Zjednoczone Ameryki. Konstytucji 3 Maja nie dane było rzeczywiście naprawić państwa i ustroju, jedynie wzmocniła ona ducha narodowego i zintegrowała marzenie o własnej i niezależnej państwowości. Po odzyskaniu niepodległości w 1918 r. opracowano i uchwalono aż dwie konstytucje, ale jedna $\mathrm{z}$ nich okazała się antydemokratyczna. Z nią państwo wstąpiło w okres wojny i okupacji. Po wojnie ład konstytucyjny stworzono na podstawie Konstytucji PRL, na której zmiany osobiście nanosił Józef Stalin - fakt ten zaważył na jej charakterze. W wyniku przemian 1989 r. udało się doprowadzić do demokratyzacji systemu prawnego. Na tym tle dopiero widać, jak ważną rolę stabilizującą pełni obowiązująca Konstytucja, bowiem na jej podstawie zrodziła się wreszcie szansa zbudowania kultury konstytucyjnej i prawnej.

Wspominając swój udział i przewodnictwo w Komisji Konstytucyjnej Zgromadzenia Narodowego (która uchwaliła projekt Konstytucji z 1997 r.), Prelegent przywołał swą rozmowę z prof. Bronisławem Geremkiem, który nie wierzył, by Sejm z większością udziału partii lewicowych był zdolny do uchwalenia ustawy zasadniczej. Podobnie sceptyczny pogląd wyrażał wówczas Tadeusz Mazowiecki.

Mimo to, szerokiej koalicji Unii Wolności, Unii Pracy, Sojuszu Lewicy Demokratycznej i Polskiego Stronnictwa Ludowego udało się doprowadzić do zakończenia prac konstytucyjnych. Trwały one 4 lata, a poprzedzały je 2 lata debaty w Sejmie poprzedniej kadencji. Już sam fakt długości prac nad Konstytucją powinien, zdaniem Prelegenta, ostudzić powracające zamiary dokonywania w niej zmian szybkich i dyktowanych potrzebą politycznej chwili.

Niezaprzeczalną siłą i zarazem wartością tej Konstytucji jest jej oparcie na pluralistycznych poglądach, wynikających z przyjęcia założenia o samoistnej wartości kompromisu rozumianego nie jako przejaw słabości, lecz siły jako dążenie do pogodzenia rozbieżnych interesów. Było to możliwe dzię- 
ki podjęciu prac konstytucyjnych w konkretnym kontekście historycznym. Udało się w ustawie zasadniczej uniknąć błędów i wypaczeń jej poprzedniczki z 1952 r., np. w zakresie ochrony praw człowieka i obywatela. Na treści obecnie obowiązującej Konstytucji zaważył również kontekst ówczesnych doświadczeń życia publicznego, np. prezydentura Lecha Wałęsy i wspierająca ją „falandyzacja prawa”, w których upatrywać należy jedną z przyczyn wprowadzenia systemu mieszanego, a nie prezydenckiego. Drugą przyczyną była niestabilna sytuacja rządowa, skutecznie odżegnująca twórców Konstytucji od modelu parlamentarnego.

Prelegent zauważył, że nader często pytany jest o to, które z regulacji były kontrowersyjne w trakcie prac konstytucyjnych. Odpowiada wówczas, że w zasadzie jedynie przepis dotyczący uznania Warszawy za stolicę państwa nie budził wątpliwości. Najbardziej zacięte dyskusje toczono wokół czterech zagadnień: a) relacji między władzami, b) relacji między państwem a kościołem katolickim, c) wolności i praw obywatelskich, d) możliwości przekazywania do wykonywania części suwerennych praw państwa na organizacje i organy międzynarodowe.

Zdaniem Prelegenta, dzięki pomyślnemu rozwiązaniu tych spornych zagadnień oraz dzięki nader ogólnemu, lecz trafnemu zdefiniowaniu państwa polskiego jako demokratycznego państwa prawnego, urzeczywistniającego zasady sprawiedliwości społecznej, Konstytucja z 1997 r. sprawdziła się w praktyce i odgrywa pozytywna rolę.

Fakt ten nie oznacza jednak, że nie może być zmieniana - jest niedoskonała jak każdy twór człowieka. Niemniej nie można potencjalnych zmian wykorzystywać do bieżących rozgrywek politycznych. Przemyślanym propozycjom zmian służyć może jedynie świadoma, ogólnospołeczna debata. Nie można bowiem, pod żadnym pozorem, doprowadzić do degradacji rangi ustawy zasadniczej do ustawy zwykłej. Gdyby tak było, czekałaby Polskę sytuacja rodem z Ukrainy, gdzie nikt w zasadzie nie wie, która konstytucja obowiązuje. Wynika stąd, co wielokrotnie podkreślił Prelegent, że stabilność konstytucji jest wartością samoistną.

Stawiając kolejne pytanie - co dalej? - Prelegent wskazał, że co prawda dyskusja konstytucyjna jest potrzebna, a szczególnie mocno legitymowany do jej rozpoczęcia jest aktualny piastun urzędu prezydenckiego, to nie sposób pogodzić się z bezpardonowym dezawuowaniem funkcji i pozycji Konstytucji. 
Jest to nie tylko niedojrzałe i niebezpieczne dla państwa, ale i zupełnie niezrozumiałe, skoro obowiązkiem Prezydenta jest czuwanie nad przestrzeganiem Konstytucji, na której podstawie sam został wybrany na urząd. Jednocześnie sama krytyka, która często sprowadza się jedynie do zarzucania Konstytucji postkomunistycznego pochodzenia, nie jest wystarczająca. Krytycy obecnie obowiązującej Konstytucji winni przedstawić konkretne projekty zmian. Nie czynią tego, a ich wątpliwe propozycje mogą skutkować jedynie regresem wobec obecnego standardu konstytucyjnego.

Przestrzegając przed pochopnymi propozycjami zmian Konstytucji RP z 1997 r., Prelegent wskazał, że konieczne jest odpowiednie uświadomienie społeczeństwa o potrzebie, zakresie i kierunkach zmian. W tym celu, gdy sam pełnił funkcję głowy państwa, przesłał do każdego gospodarstwa domowego w Polsce tekst Konstytucji RP. To pozwoliło na podniesienie świadomości konstytucyjnej członków wspólnoty narodowej i rozpoczęło żmudną drogę do wypracowania szacunku dla Konstytucji. Tylko w ten sposób poinformowani obywatele mogli podjąć dojrzałe decyzje w referendum konstytucyjnym.

Na tym zakończyła się pierwsza część spotkania i rozpoczął się czas na pytania. W odpowiedzi na pytanie dotyczące osobistych doświadczeń i nauk związanych z pracami przy Okrągłym Stole i w Komisji Konstytucyjnej Zgromadzenia Narodowego, Prelegent wskazał, że najważniejszą z nauk była nauka poszukiwania kompromisu. Przypomniał, że nie raz już stwierdzał, że „jego drugie imię to Kompromis". W nim bowiem tkwi siła demokracji. Tylko kompromis zapewnia urzeczywistnianie woli demokratycznej większości, a jednocześnie uwzględnienie woli i interesów mniejszości.

W odpowiedzi na dalsze pytania, Prelegent przywołał część ze swych licznych wspomnień ze spotkań i rozmów z wielkimi światowymi osobistościami. W szczególności podkreślił swe doświadczenia ze spotkań z Ojcem Świętym Janem Pawłem II i Królową Elżbietą II.

Na tym zakończono spotkanie. Okazało się być ono nader owocne i pouczające

Jan Uniejewski Uniwersytet Szczeciński 